\title{
The role of knowledge economy in Asian business
}

\author{
Shumaila Zeb*
}

\begin{abstract}
The study examines the role of the knowledge economy (KE) in Asian businesses in 45 countries for 2000-2019. KE indicators include education, economic incentives, innovation, institutional regime, and information and communication technology. The business indicators used in the study are starting, doing, and closing business. The empirical analysis is carried out by applying principal component analysis (PCA) and instrument variable panel fixed effects estimator. The results proved that the KE indicators are essential to improve businesses in Asia. They help the economies to boost their business sector and help to fight against poverty and unemployment.
\end{abstract}

Keywords: Knowledge Economy, Business growth, Asian Business

JEL Classification: L59, O10, O20, O50

\section{Introduction}

For the last two decades, economies of the world have been striving to evolve themselves to become knowledgebased economies (KBE). KBE relies less on traditional sources like land, labor, and capital for asset creation, wealth maximization, and economic prosperity [6, 7]. In today's world, the formation of new knowledge, research and development (R\&D) to promote innovation and technological advancements to achieve prosperity is the key to success $[47,66]$. Similarly, the governments' economic incentive based on new knowledge creation stimulates economic development, favors entrepreneurship, and increases employment opportunities in the economy. These existing trends, based on the creation and dissemination of new knowledge, are welcomed in developing and emerging economies. These are considered as the backbone of a KBE [65]. Similarly, knowledge economy (KE) is an expression used in developed economies to explain critical factors of knowledge creation and its usage as a means of production to gain competitive advantage and enhance efficiency and productivity.

*Correspondence: shumaila.zeb@gmail.com

Shaheed Zulfikar Ali Bhutto Institute of Science and Technology,

Islamabad, Pakistan
$\mathrm{KE}$ and KBE's roots are originated from different economic theories. Like, Neo classical economics and idea of increase returns to scale led toward knowledge-based economy. Different theories like endogenous growth theory (Romer 1990), organizational theory [62], and the theory of transaction cost [38] laid foundation of knowledge-based economy. Indeed, knowledge is nowadays considered as a driving force for enhancing productivity, promoting economic development, and increasing economic performance. KE does not only refer to employing new means for the production of goods and services but it also requires a complete novel paradigm. This new paradigm involves innovation, new technology, and high skilled human force in every sector of the economy.

Innovation is considered as one of the potential determinants of economic growth and prosperity in the developed world. It is one of the important pillars of KE. However, it is observed that the capacity of innovation remains less in most Asian and African economies [19] and [5]. Globalization is another critical factor, which also plays an essential role in the KBE. The globalization of new technology creates more opportunities for development and growth in the developing and emerging economies [48]. However, the situation is a bit different in certain economies including Asian economies. They 
need to invest more in human capital and infrastructure to accommodate and sustain high technology-oriented ventures and industries. Therefore, developing countries need to cooperate more with the developed world to increase their competitiveness and international trade goals $[32,39,65]$.

In the light of the above, there are various studies on the relevance of KBE and KE. Several studies have been conducted on the relevance of human capital. Examples of these studies include Schultz [58] and the creation of growth models by Romer [55] and Lucas [41] made knowledge and human capital significant factors for growth. The roots of KE go back to the industrial revolution from the 1760 s to the 1850 s, when technological innovation boosted economic expansion [36]. Traditionally, there was more dependence on labor and capital as the primary sources of economic growth and development. However, the past two decades witnessed the vital role of $\mathrm{KE}$ in developed and developing economies [10]. No doubt, Asian countries are self-sufficient in the labor force [43]. However, now trends have changed due to technological advancements in producing goods and services. Asian economies contribute significantly in the GDP of the world. As per the income distribution, few Asian economies are at middle-income levels. Therefore, the Asian economies need to develop a KBE culture to enter into high-income levels like other developed countries. They must devise policies to improve their information infrastructure, communication and information, and human capital to become successful KBE [52, 52].

The prominent examples of KBEs in Asia are the Republic of Korea, Singapore, China, India, Japan, Singapore, and Indonesia [65]. China is spending about $2 \%$ of its GDP on innovation [31]. Indonesia is spending considerable investments in education and innovation. India is also contributing toward promoting knowledge-based culture to boost its economy. During the past decade, Bangladesh has shown tremendous progress in information and communication technology (ICT) which opened doors to many industries. During the past few years, Sri Lanka turned out to have the highest KE index followed by India, Nepal, and Pakistan. The Republic of Korea's customized training programs prompted fruitful business and human capital formation [61]. All these efforts confirm the value and importance of KE for sustainable, long-lasting economic growth and development.

The above sets of the narrative are consistent with the need to assess potential factors helping to encourage the KBEs in Asia. However, when we look at the empirical literature, we find that there is relatively less literature available on assessing the KE factors in relevance to the business development in Asia. Yet, for making effective and sound policies to promote and harvest the benefits of
$\mathrm{KE}$, it is important to empirically know how KE indicators are significant for boosting businesses in Asia. Therefore, this study provides first-hand empirical evidence and is vital because of the following reasons. Asian economies are striving to achieve a higher level of KE. They have a high potential to improve their existing knowledge and become more competitive to enhance their economic development and adapt globalization challenges. Further, KE helps the economies to enhance the quality of life of a common man, provide better investment and employment opportunities resulting in higher and sustainable economic growth. Therefore, the main objective of the study is to examine the role of KE in Asian businesses in 45 countries for the period 2000-2019. KE dimensions are reduced using the PCA to control the issues of multi-colinearity and over-parameterization. The other estimation technique used in the study is instrumental variable panel fixed effects. To cater to the complete life cycle of business, the business is subdivided into three categories, i.e., starting business, doing business, and closing business. The four KE components of the World Bank are used in the study. These components are education, innovation, economic incentives \& institutional regime, and information and communication technology. The results provide strong evidence that education, economic incentives, and ICT help to decrease the time and cost of starting a new business. Further, the results show that innovation and inflation increase the time to start a new business. Similarly, education and innovation help decrease the trade barriers while doing business. It is also observed that ICT helps to lower the cost of exports in doing business. Economic incentives reduce business closure and insolvency. This empirical investigation is unique in its contribution. It contributes to the limited literature available on the Asian KBEs and the increasing challenges of enhancing business development using KBE and KE.

The remainder of the study is organized as follows. The relevant literature is discussed in Section II. Section III elaborates the data, sample selection, and variables description. Section IV presents the methods used in the study. Results and discussion are given in Section V. Conclusion and policy implications are discussed in the last section.

\section{Literature Review}

There are a number of empirical studies regarding the effects of KE dimensions on economic expansion [61]. For example, Hadad [28] proved that KE prompts economies to have vibrant and flexible schemes depending on stateof-the-art production elements, influences e-commerce, and other technological advancements while increasing economic benefit. According to Barkhordari, Fattahi, and 
Azimi [12], new knowledge creation and dissemination always lead to prompt a dynamic competition. In a recent study, Asongu et al. [11] discussed business dynamics, $\mathrm{KE}$, and economic performance of 53 African countries from 1996 to 2010. Their main findings indicated that the dynamics of starting and doing business and changes in $\mathrm{KE}$ are strongly correlated to each other. Furthermore, a weak correlation is observed between $\mathrm{KE}$ and the economic performance of the underlying countries.

The knowledge that comprises reliability, specialization, and contestability features are considered to be powerful [70]. Harris and Ormond [29] concluded that relevant policymakers must focus on understanding and making adequate knowledge frameworks rather than pushing education through generic terms. In the context of Europe, Raspe and Van Oort [53] analyzed the contribution of knowledge toward economic growth. They used three main components of KE: knowledge workers, innovation, and R\&D along with several other variables. They revealed that innovation and knowledge workers were more related to economic growth. According to authors, policymakers must preferably consider all three components while devising any regulation.

Despite an extensive literature showing the significant impact of KE on economic growth, Liargovas and Repousis [40] found some interesting results in Greece from 2007 to 2013. They used knowledge capital, business capital, and the stock of physical and labor capital in 51 Greek regions. The results demonstrated that in comparison with knowledge capital, business capital has a more profound impact on economic growth. They recommended that policymakers and regulators must also consider entrepreneurship as a tool for spreading knowledge. In another study, Bogoviz et al. [13] investigated the role of human in the economic system under the conditions of KE in Russia. They used correlation analysis to find the dependence of KE on different types of resources, i.e., technological, human, material, and investments for the period 2010-2016. They concluded that KE provides more opportunities in the source of creation, implementation, and dissemination of innovational goods. This leads humans to become active innovational entrepreneurs.

In the African countries' context, Amavilah et al. [3] investigated how globalization affects peace and stability through the channel of governance and KE. The authors used the instrumental variable panel fixed effects estimation econometric approach for a sample of 53 African countries for the period 1996-2010. They found that sustainability in KE can only be achieved if African countries pursue such globalization policies that result in peace and stability. Similarly, Muzaka [47] conducted a study on competitive KE in two emerging states India and Brazil for the 1990s. The findings revealed that strong nationalist sentiments are the pillars on which India and Brazil built this new orientation toward becoming successful $\mathrm{KBE}$. However, these types of sentiments are not present in advanced economies. Likewise, Dima et al. [21] analyzed the relationship between $\mathrm{KE}$ and global competitiveness in the European Union (EU). They used various indicators of KE such as R\&D expenditure, lifelong learning, GDP per capita, percentage of the population with tertiary education, and debt to equity. They found that innovation and education play a crucial role as predictors of economic growth. However, they concluded that focus on R\&D activities and lifelong learning possibilities could significantly contribute to competitiveness in EU member states.

Similarly, the role of new knowledge capital in firm production and industrial growth is analyzed by Woods et al. [69]. He used two productions and one learning model. He concluded that a firm might experience a decrease in knowledge capital under diminishing returns. He found that when a firm updates its knowledge capital, it not only increases its productivity but it also has a spillover effect on the whole industry. Nurunnabi [50] examined how Saudi Arabia is swiftly transforming itself into a KE. The findings demonstrated that despite the rapid transformation of Saudi Arabia into a KBE from the last few decades, some steps are needed to be implemented to avail full-scale advantages of KE. He further suggested that Saudi Arabia must increase its GDP allocation toward further R\&D process. Also, reducing unemployment in female graduate students and rising human capital are some key issues that need attention from the relevant authorities.

Several studies proved that education helps to improve the KE level in any economy. For example, Evoh et al. [22] analyzed how different aspects of $\mathrm{KE}$, especially higher education institutions, and the application of ICT innovations influence capacity development in Africa. They used different learning institutions in Kenya and Uganda as case studies. The results revealed that knowledge production for the advancement of African economies is not fulfilled by the higher education system. They further suggested that higher education institutions must engage in design-driven innovation and employ public-private initiatives in universities and research institutions.

On the relevance of education in the context of the global economy, Bogoviz et al. [14] analyzed the regularities and tendencies of globalization of education required in $\mathrm{KE}$ in nine different economies. They used various qualitative and quantitative measures and found a significant association between multiple indicators of $\mathrm{KE}$ on the globalization of education. They discovered that globalization of education increased the creation of KE. 
The results revealed that from 2016 to 2018, the tendencies showed decreased foreign lectures and an increase in international students. Similarly, Hassan and Cooray [30] proved the vital role of education in economic growth. They examined the effects of school enrollment on economic development taking a variety of gender groups from the Asian perspective. They found that the results of education are considered positive for both males and females at all educational levels including primary, secondary, and tertiary ones.

Wantchekon et al. [67] found that the benefit of educating one generation can develop a better attitude toward education and learning in the coming generations. Even educated relatives can transfer their knowledge to extended family members. This transfer of knowledge was not seen in the uneducated family and friends. In terms of Asian countries, Hongyi and Huang [33] conducted a study on health, education, and economic growth in China. They used a panel data set of 28 provinces in China for the period 1978-2005. After employing panel regression two-stage least square regression analyses, they found that both education and health are positively associated with economic growth.

Similarly, Gyimah-Brempong et al. [27] analyzed the role of higher human education capital on the economic growth of African countries using a dynamic panel data estimator from 1960 to 2000. The findings revealed that the growth rate per capita income is significantly related to higher education human capital. Their results imply that both economic growth and education human capital rely on physical capital investments. In another study, Moodie and Wheelahan [46] criticized that generic education delivered is a product rather than a process by which knowledge can be derived. He further argued that the curriculum approach of teaching knowledge must be altered from generic to disciplinary methods. This would help intelligent knowledge users. He further argued that intelligent knowledge users could learn through history. They can easily relate past knowledge to solve problems of the present and future.

Innovation is considered to be one of the most important elements that contribute to KE and business performance. The expansion of the global economy rests upon the fundamental strands of open innovation. Thus, the creation, use, and management of knowledge drive both competitiveness and productivity [68]. In the innovation dimension, Agénor and Neanidis [1] found that an extra innovation routine enhances economic growth. It was studied in the role of R\&D spending in the economic progress of 66 economies during the period 2000-2009. The results found that R\&D spending positively affected the growth in upper-middle-income countries [34]. Castellacci and Natera [15] also proved positive relationship between strong innovation policies and economic development.

Gabriele et al. [25] analyzed the R\&D collaborations in the regional context. The findings elaborated that knowledge represented by public research institutions is the primary source that firms use for collecting knowledge. Furthermore, they found that smart firms acquired knowledge from sources outside the region and did not primarily rely on local knowledge hubs. In another study, the relationship between transmission power and indicators of KE in six OECD countries (USA, Canada, France, Germany, Japan, and South Korea) is analyzed by Mêgnigbêto [44]. The results indicated that for 20012010 in South Korea and Japan, there is a strong positive correlation between gross domestic expenditure for $R \& D$ and transmission power.

Information, communication, and technology have been game-changer in KBE. Firms can achieve sustainable competitive advantage in high-tech industries. By keeping in mind this perspective, Martín-de Castro [42] explained one of the most complex business phenomena in the form of a firm's technological advantage. He proved that a firm could never achieve higher strands of innovation in isolation. External relationships develop better and faster innovations. Das et al. [17] and Jorgenson and Givens [37] proved that ICT is positively related to economic development. They concluded that ICT investment had a positive and significant effect on the development of the global economy.

Barkhordari et al. [12] found that the MENA region is investing its revenue in construction schemes, ICT, and good health facilities to improve its economic condition. He further added that strong financial institutions would favor investing in new technology to enhance economic growth. In terms of Asian countries, Ahmed and Ridzuan [2] used the panel estimation approach to investigate the impact of ICT on East Asian economic growth from 1975 to 2006. They used ICT investments, capital, and labor as independent variables while the real gross domestic product (GDP) is used as a dependent variable of the study. The findings indicated that investments in ICT products are positively and significantly related to GDP. They recommended that East Asian countries must invest more in ICT products to achieve sustainable growth in the long-run period.

Datta and Agarwal [18] used data for 22 OECD countries and analyzed the long-run association between telecommunication infrastructure and economic growth. They revealed that both variables are positively and significantly related to each other. Similarly, Roller and Waverman [54] found that demand for telecoms is significantly and positively associated with GDP for 1970 to 1990 for a sample of 36 countries. In 
the case of Singapore, Poh, Ang, and Bai [51] analyzed the impact of ICT investments on productivity from 1977 to 1997 using Cobb-Douglas production. The main findings indicated that productivity maintained a positive and significant relationship with ICT investments. Similarly, Niininen [49] also concluded that ICT has a substantial impact on real growth output in Finland.

Shahbaz et al. [60] analyzed the relationship between ICT and electricity demand in the UAE by using cointegration for 1975-2011. They found that electricity consumption increased by the use of ICT. The causality analysis proved that electricity consumption does not Granger causes ICT, but the same is true for the opposite side. However, electricity prices Granger causes both economic growth and ICT. They suggested the use of smart ICT infrastructure and an increased focus on energy-efficient $R \& D$ policies help to achieve sustainable economic growth. In the same line, Sadorsky [57] analyzed the impact of ICT on electricity consumption. They used Internet connections, mobile phone users, and the number of personal computers as a proxy for ICT. The findings demonstrated a positive association between ICT and electricity consumption. Likewise, Ishida [35] found a long-run stable relationship between the demand for energy and production function from 1980 to 2010 in Japan. They used multivariate models related to demand for energy and production function. Moreover, comparative analysis between emerging and G7 countries on various aspects of KE and total factor productivity (TFP) is done by Shahabadi et al. [59]. They used panel data analysis for the period 1996-2013. The results indicated that the ratio of ICT capital stock to GDP and the ratio of foreign R\&D capital stock to GDP have the greatest positive impact on TFP. The results largely imply that emerging economies adopt new production factors such as domestic R\&D and innovation while leaving behind traditional production factors.

Political institutions make economic institutions. The strategies and policies made by the economic institutions result in economic growth. Hence, it concludes that political institutions provide the impetus for economic development [23]. Similarly, Asongu and Andrés [9] found that the absence of adequate credit facilities harms the growth of KEs in Africa and Middle East countries. In respect of the innovation aspect, they noted that the lack of technical and scientific publications is restricting these economies from obtaining the full benefits of KBEs. The finding further proved that the time required for full convergence from low to high level of KE is about 4 to 7 years.

\section{Data Description, Sample Selection, and Variables Description}

The recent study uses a panel of 45 Asian countries. Initially, all Asian countries were used as a sample of the study. However, Lebanon, Japan, and Turkmenistan are excluded from the sample due to the non-availability of data. List of the countries included in the sample is given in Appendix A-1. The data begin from 2000 because for Asian countries, data for education and the institutional regime were available from this year. The annual data related to the variables used in the study are extracted from the World Bank indicators (WDI) for the period 2000-2019.

Following previous literature Tchamyou [65], we classified business into three categories, i.e., starting, doing, and closing the business. The three phases described in the study are used to cover the complete life cycle of a business. The starting business includes three indicators. They are time required to start a new business, the cost of starting a new business, and the number of newly created businesses. The doing business phase indicators include trade openness, technology exports, and property rights institutions. The ending business phase includes the time required to resolve insolvency. These business indicators are used as dependent variables. A detailed description of the dependent variables is given in Table A-2. The World Bank's KE indicators show a complete picture of all aspects of an economy [64]. Therefore, following the World Bank, we also used the same indicators, i.e., innovation, education, institutional regime \& economic incentives, and ICT as independent variables. Due to extensive issues of multi-collinearity and overparameterization, we derive each dimension of KE using the PCA. Each dimension of KE used in the study is given in Table A-2.

We also control for the macroeconomic indicators. Only those indicators are used which might influence the different phases of the life cycle of a business. These are inflation, government expenditure, and GDP growth. Inflation is expected to be negatively associated with the business. GDP growth is expected to be positively associated with all the indicators of the business. However, government expenditure depends upon a number of other factors, including budget allocation and misallocation or malpractices like corruption. Therefore, we cannot predict its sign. Empirical definitions of the variables are given in Table A-2.

\section{Methods}

KE indicators are used as independent variables of the study. It is expected that all independent variables are correlated with each other or with the component 
variables. Therefore, it requires employing an estimation technique that tends to reduce a large number of correlated variables into a small set of uncorrelated variables known as principal components. Therefore, we used the PCA following Tchamyou [65] and Asongu [8] for each of the KE indicators. They also recommend dropping the factors having an Eigenvalue less than one. Therefore, each of the dimensions of KE is reduced by PCA to produce various indices. Education included primary school enrollment, secondary school enrollment, and tertiary school enrollment. Education is reduced by the use of the PCA to Educatex index. Similarly, ICTex, Creditex, Instireg, and Innovex indices are also created using the PCA.

We used instrument variable panel fixed effects following Tchamyou[65]. Two stages of regressions are estimated for each variable. In the first-stage of regression, we regress the KE indicators separately on their first lags with robust heteroskedasticity and autocorrelation consistent (HAC) standard errors. The fitted values obtained from the first regressions are then used in the second stage of regressions. The second-stage regressions are also HAC and further controlled for the unobserved heterogeneity and multi-collinearity to avoid biased estimates.

$$
\begin{aligned}
K E_{i t}= & \Upsilon o+\Upsilon_{1}(\text { Instruments })_{i t} \\
& +\Upsilon_{j}(\text { Control Variables })_{i t}+v_{i t}
\end{aligned}
$$

$$
\begin{aligned}
\text { Bu sin ess } i t= & \beta o+\beta_{1}\left(\text { Educatex }_{i t}+\beta_{2}(\text { ICTex })_{i t}\right. \\
& +\beta_{3}\left(\text { Creditex }_{i t}+\beta_{4}(\text { Instireg })_{i t}\right. \\
& +\beta_{5}(\text { Innovex })_{i t}+\beta_{j}(\text { Control Variables })_{i t} \\
& +\varepsilon_{t}+e_{i t}
\end{aligned}
$$

KE is presented by Educatex, ICTex, Creditex, Instireg, and Innovex indices created by the PCA. Instruments are used in the first equation are lags of the endogenous variables. Business is further divided into starting, doing, and closing business. Separate regressions are estimated for each category of business. Control variables used in the study are inflation, GDP, and government expenditures. $v_{i t}$ and $e_{i t}$ are the error terms. $\varepsilon_{t}$ is the time-specific constant.

\begin{tabular}{|c|c|c|c|c|c|c|}
\hline & Variables & Obs & Mean & Std Dev & Min & Max \\
\hline \multirow[t]{5}{*}{ Knowledge Economy } & Educatex & 425 & -0.012 & 1.00 & -1.54 & 8.181 \\
\hline & ICTex & 772 & -0.002 & 1.11 & 0.305 & 8.492 \\
\hline & Creditex & 558 & -0.049 & 0.94 & 1.664 & 3.634 \\
\hline & Instireg & 731 & 0.001 & 1.00 & -2.495 & 2.878 \\
\hline & Innovex & 632 & 0.084 & 1.39 & -0.374 & 17.239 \\
\hline \multirow[t]{4}{*}{ Starting Business } & Time to Start(log) & 621 & 1.476 & 1.509 & 1 & 2.27 \\
\hline & Cost to start(log) & 731 & 2.570 & 3.390 & 0 & 4.616 \\
\hline & New business density & 435 & 2.229 & 4.18 & 0.067 & 1.59 \\
\hline & New business registration(log) & 435 & 4.208 & 4.328 & 1.128 & 5.093 \\
\hline \multirow[t]{9}{*}{ Doing Business } & Cost to export(log) & 252 & 2.264 & 2.45 & 0.00 & 3.255 \\
\hline & Trade Tariff & 600 & 6.830 & 17.672 & 0.00 & 421.5 \\
\hline & Trade Openness(log) & 860 & 1.76 & 2.239 & 0.00 & 3.225 \\
\hline & ICT goods exports & 566 & 7.38 & 12.45 & 0.00 & 54.97 \\
\hline & ICT services exports(log) & 588 & 9.39 & 9.970 & 4.165 & 1.894 \\
\hline & High-technology exports(log) & 340 & 10.511 & 11.001 & 2.079 & 11.816 \\
\hline & Contract Enforcement(log) & 651 & 2.801 & 2.554 & 120 & 3.435 \\
\hline & Registration of property(log) & 600 & 1.691 & 1.816 & 1 & 2.475 \\
\hline & Investor protection: Disclosure & 645 & 6.09 & 2.52 & 0 & 10 \\
\hline Closing Business & Insolvency resolution & 565 & 2.679 & 1.296 & 0.8 & 6 \\
\hline \multirow[t]{3}{*}{ Control Variables } & Inflation & 776 & 5.742 & 7.026 & -18.108 & 57.0745 \\
\hline & GDPg & 800 & 5.501 & 5.830 & -33.100 & 64.0812 \\
\hline & GExp & 747 & 14.552 & 9.266 & 3.460 & 135.809 \\
\hline
\end{tabular}

\section{Results and Discussion}

This section presents the summary statistics and regression results of the study. Table 1 presents the summary statistics of the variables used in the study. The value

Table 1 Summary statistics of Asian countries 
of the standard deviation of different variables shows a significant variation. Therefore, we are confident that a few important estimated relationships would be derived from the estimations. The negative mean of Education indicates that the Education level in Asia is very low. Efforts are required to increase the education level of the Asian economies. Similarly, Information and technology, and credit enhancing facilities from the financial institutions to the other sectors of the economies also need to be improved in these economies. The mean value of innovation indicates that there is less innovation in Asian economies. The standard deviation to of all the components of starting a business shows a high variation in starting the business in Asian economies.

Tables 2, 3, and 4 present the estimated coefficients obtained from the regression analyses. A separate regression is estimated for each business phase. The estimated coefficients are presented in the tables followed by the standard errors in parenthesis. The information required for the validation of the models used falls under the acceptable criterion. The F-statistics indicate that all the models used in the study are fit and valid. Overall, all the models have a high significance level of $1 \%$.

The study used four business indicators to explain a business start-up. The estimated coefficients of time to start a business and cost to start a business suggest that both variables are negatively and significantly related to education. The results suggest that education helps individuals to decrease the time and cost to start a business. However, the results also show that education is significantly and positively related to the new business density. The result implies that education helps to increase business density. The result also implies that students who undertake certain entrepreneurial activities during their undergraduate and graduate programs help to improve the poverty level of the economy. The education also improves the negotiation and conflict management of the students which helps them to reduce the time and cost to start a business. The results are consistent with the findings of Singh [63] and Gerba [26].

The estimated coefficient of economic incentives shows that it is negatively and significantly related to the time to start a business. The result also shows that an economic incentive is positively and significantly related to the new business registrations as well. The results imply that economic incentives favor new business ventures in the economies. It helps to reduce the time to start a new business and increase the number of businesses in an economy. The estimated coefficient of Creditex shows that if everything remains equal, a one-unit change in the economic incentive will decrease the time to start a business by 0.85 units on average. Similarly, the estimated coefficient of Creditex shows that everything remains equal; a one-unit change in the economic incentive will

Table 2 Regression results of starting a business

\begin{tabular}{lllll}
\hline Variables & Time to start a business & Cost to start a business & New business registration & New business density \\
\hline Constant & $0.226^{* *}$ & 0.806 & $0.547^{*}$ & $1.561^{* *}$ \\
Educatex & $(0.057)$ & $(0.694)$ & $(0.234)$ & $(0.657)$ \\
Creditex & $-0.870^{* *}$ & $-0.574^{* *}$ & 0.772 & $1.746^{* *}$ \\
& $(0.225)$ & $(0.173)$ & $(0.642)$ & $(0.721)$ \\
Innovex & $-0.857^{* *}$ & -0.142 & $0.969^{* *}$ & $(0.147$ \\
& $(0.249)$ & $(0.748)$ & $(0.258)$ & $-0.553^{* * *}$ \\
Instireg & $1.353^{* *}$ & -0.442 & $0.984^{* * *}$ & $(0.135)$ \\
ICTex & $(0.336)$ & $(0.172)$ & $(0.165)$ & $-2.234^{* * *}$ \\
Inflation & $0.677^{* * *}$ & 0.803 & $0.618^{* * *}$ & $(0.873)$ \\
& $(0.155)$ & $(0.702)$ & $(0.141)$ & 0.147 \\
GDPg & $-0.714^{* *}$ & 0.374 & $0.754^{* * *}$ & $(0.241)$ \\
GExp & $(0.254)$ & $(0.607)$ & $(0.104)$ & $-0.285^{* *}$ \\
No. of obs & $0.432^{*}$ & -1.850 & -1.091 & $(0.141)$ \\
R & $(0.151)$ & $(1.872)$ & $(1.252)$ & $0.272^{* *}$ \\
F-stat & -0.177 & $-0.398^{* *}$ & 0.405 & $(0.190)$ \\
Prob(F-stat) & $(0.231)$ & $(0.059)$ & $(0.643)$ & $-0.254^{* *}$ \\
\hline
\end{tabular}


Table 3 Regression results: doing business (trade and technology rights)

\begin{tabular}{|c|c|c|c|c|c|c|}
\hline Variables & Cost of Exports & Trade Barriers(tariff) & Trade Openness & ICT goods export & ICT Services Export & $\begin{array}{l}\text { High- } \\
\text { technology } \\
\text { Exports }\end{array}$ \\
\hline Constant & $\begin{array}{l}0.352 \\
(0.671)\end{array}$ & $\begin{array}{l}0.656^{* * *} \\
(0.116)\end{array}$ & $\begin{array}{l}0.412^{* * *} \\
(0.151)\end{array}$ & $\begin{array}{l}0.779^{*} \\
(0.303)\end{array}$ & $\begin{array}{l}0.930^{* * *} \\
(0.263)\end{array}$ & $\begin{array}{l}2.481^{* *} \\
(1.642)\end{array}$ \\
\hline Educatex & $\begin{array}{l}0.671^{* *} \\
(0.172)\end{array}$ & $\begin{array}{l}-0.372^{* *} \\
(0.134)\end{array}$ & $\begin{array}{l}1.755 \\
(1.311)\end{array}$ & $\begin{array}{l}2.869 \\
(1.844)\end{array}$ & $\begin{array}{l}1.731^{* *} \\
(0.552)\end{array}$ & $\begin{array}{l}0.301 \\
(0.164)\end{array}$ \\
\hline Creditex & $\begin{array}{l}-0.867 * * \\
(0.484)\end{array}$ & $\begin{array}{l}-0.881^{* * *} \\
(0.173)\end{array}$ & $\begin{array}{l}0.697 \\
(0.438)\end{array}$ & $\begin{array}{l}-0.687 \\
(2.242)\end{array}$ & $\begin{array}{l}1.223^{*} \\
(0.471)\end{array}$ & $\begin{array}{l}1.631 \\
(1.293)\end{array}$ \\
\hline Innovex & $\begin{array}{l}1.221 \\
(1.824)\end{array}$ & $\begin{array}{l}-0.1111^{* *} \\
(0.051)\end{array}$ & $\begin{array}{l}-1.727^{* * *} \\
(0.491)\end{array}$ & $\begin{array}{l}0.711^{* *} \\
(0.325)\end{array}$ & $\begin{array}{l}1.334^{* * *} \\
(0.576)\end{array}$ & $\begin{array}{l}-0.721^{* *} \\
(0.235)\end{array}$ \\
\hline Instireg & $\begin{array}{l}1.137 \\
(1.241)\end{array}$ & $\begin{array}{l}-0.732 \\
(0.646)\end{array}$ & $\begin{array}{l}0.254 \\
(0.295)\end{array}$ & $\begin{array}{l}0.096 \\
(1.536)\end{array}$ & $\begin{array}{l}1.682 \\
(1.823)\end{array}$ & $\begin{array}{l}1.745 \\
(1.253)\end{array}$ \\
\hline ICTex & $\begin{array}{l}-0.811^{* *} \\
(0.357)\end{array}$ & $\begin{array}{l}-0.532^{* * * *} \\
(0.126)\end{array}$ & $\begin{array}{l}0.666 \\
(0.327)\end{array}$ & $\begin{array}{l}1.785^{* * *} \\
(0.598)\end{array}$ & $\begin{array}{l}2.041 \\
(1.734)\end{array}$ & $\begin{array}{l}1.536^{* *} \\
(0.682)\end{array}$ \\
\hline Inflation & $\begin{array}{l}-0.819^{* *} \\
(0.342)\end{array}$ & $\begin{array}{l}-2.498^{* * * *} \\
(0.763)\end{array}$ & $\begin{array}{l}-2.753 \\
(1.796)\end{array}$ & $\begin{array}{l}0.491^{* *} \\
(0.138)\end{array}$ & $\begin{array}{l}1.783 \\
(1.652)\end{array}$ & $\begin{array}{l}3.225^{* *} \\
(1.687)\end{array}$ \\
\hline GDPg & $\begin{array}{l}-1.148 \\
(0.918)\end{array}$ & $\begin{array}{l}-0.372 \\
(0.825)\end{array}$ & $\begin{array}{l}-0.238 \\
(0.513)\end{array}$ & $\begin{array}{l}0.402^{* *} \\
(0.115)\end{array}$ & $\begin{array}{l}1.584 \\
(0.876)\end{array}$ & $\begin{array}{l}0.770^{* *} \\
(0.235)\end{array}$ \\
\hline GExp & $\begin{array}{l}2.932 \\
(1.863)\end{array}$ & $\begin{array}{l}1.965 \\
(1.438)\end{array}$ & $\begin{array}{l}3.556 * * \\
(1.501)\end{array}$ & $\begin{array}{l}-0.271 \\
(0.207)\end{array}$ & $\begin{array}{l}-0.922^{* *} \\
(0.365)\end{array}$ & $\begin{array}{l}-0.308 \\
(0.175)\end{array}$ \\
\hline No. of obs & 102 & 244 & 220 & 198 & 209 & 129 \\
\hline$R^{2}$ & 0.35 & 0.337 & 0.29 & 0.22 & 0.39 & 0.66 \\
\hline F-stat & 15.34 & 39.72 & 11.31 & 4.25 & 15.93 & 43.21 \\
\hline Prob(F-stat) & 0.00 & 0.00 & 0.00 & 0.001 & 0.00 & 0.00 \\
\hline
\end{tabular}

The estimated coefficients are given in the table followed by the standard errors in parenthesis. ${ }^{* * *},{ }^{* *},{ }^{*}$ indicates the level of significance at the $1 \%, 5 \%$, and $10 \%$, respectively

increase the number of businesses by 0.96 units on average. The results follow Wantchekon et al. [67] and Mensah and Benedict [45].

The estimated coefficient of innovation shows that it is positively and significantly related to starting a business and new business registrations. The results further suggest that innovations in any economy open new gateways in the economy. This result implies that innovation in an economy helps boost the new business start-ups in the country. However, in starting a business, the estimated coefficient shows that innovation decreases the new business density as well. The estimated coefficient of the institutional regime suggests that it is positively related to the time to start a business and business registration. However, the estimated coefficient of institutional regime indicates that it is negatively related to the new business density. This result implies that because of the large bureaucratic culture of Asia, the institutional regime results in increasing the time to start up a business and decreases the business density. The results are similar to the findings of Asongu [6,7] and Chavula and Konde [16].
The estimated coefficient of ICT suggests that it is negatively related to the time to start a business and positively related to the number of business registration. These results imply that ICT helps to reduce the time to start a new business venture. However, ICT increased the time to register the business start-up. This finding implies that maybe the population of Asia is still not technologyoriented. People are still struggling to accept the new paradigm of Information and technology. There is also another reason for this result that the Internet and communication connectivity in Asia is still not that good in comparison with the European and American countries. The results are similar to $[6,7,20]$. The results prove that education increases technological learning and favors business growth.

The estimated coefficient of inflation shows that it is positively related to the time to start a business and negatively associated with the business density. The result suggests that inflation can result in administration delays and can incur other costs on the projects. The estimated coefficient of government expenditure is negatively related to the cost of doing business and business density. 
Table 4 Regression results of doing and closing a business

\begin{tabular}{|c|c|c|c|c|}
\hline & $\begin{array}{l}\text { Contract } \\
\text { enforcement }\end{array}$ & $\begin{array}{l}\text { Registration } \\
\text { of property }\end{array}$ & $\begin{array}{l}\text { Investor } \\
\text { Protection: } \\
\text { disclosure }\end{array}$ & Insolvency \\
\hline Constant & $\begin{array}{l}0.384^{* *} \\
(0.173)\end{array}$ & $\begin{array}{l}0.297 \\
(0.303)\end{array}$ & $\begin{array}{l}0.365 \\
(0.390)\end{array}$ & $\begin{array}{l}0.603^{* * *} \\
(0.172)\end{array}$ \\
\hline Educatex & $\begin{array}{l}-0.967^{* *} \\
(0.392)\end{array}$ & $\begin{array}{l}-0.110 \\
(0.533)\end{array}$ & $\begin{array}{l}0.482 \\
(0.371)\end{array}$ & $\begin{array}{l}0.233 \\
(0.234)\end{array}$ \\
\hline Creditex & $\begin{array}{l}1.064 \\
(1.366)\end{array}$ & $\begin{array}{l}-0.615 \\
(0.799)\end{array}$ & $\begin{array}{l}0.663 * \\
(0.303)\end{array}$ & $\begin{array}{l}0.177 \\
(0.158)\end{array}$ \\
\hline Innovex & $\begin{array}{l}-0.371 \\
(0.315)\end{array}$ & $\begin{array}{l}-0.555 \\
(0.553)\end{array}$ & $\begin{array}{l}-0.403 \\
(0.712)\end{array}$ & $\begin{array}{l}0.381 \\
(0.698)\end{array}$ \\
\hline Instireg & $\begin{array}{l}0.226 \\
(0.125)\end{array}$ & $\begin{array}{l}-0.641^{* *} \\
(0.288)\end{array}$ & $\begin{array}{l}-0.027 \\
(0.025)\end{array}$ & $\begin{array}{l}-0.762^{* * *} \\
(0.174)\end{array}$ \\
\hline ICTex & $\begin{array}{l}-0.475^{* *} \\
(0.179)\end{array}$ & $\begin{array}{l}-0.804^{* *} \\
(0.393)\end{array}$ & $\begin{array}{l}0.050 \\
(0.240)\end{array}$ & $\begin{array}{l}0.967^{* *} \\
(0.364)\end{array}$ \\
\hline Inflation & $\begin{array}{l}-2.047^{* *} \\
(0.948)\end{array}$ & $\begin{array}{l}-0.574^{*} \\
(0.275)\end{array}$ & $\begin{array}{l}0.027 \\
(0.251)\end{array}$ & $\begin{array}{l}0.675 \\
(0.560)\end{array}$ \\
\hline GDPg & $\begin{array}{l}-0.397 \\
(0.976)\end{array}$ & $\begin{array}{l}-0.437 \\
(0.578)\end{array}$ & $\begin{array}{l}0.077 \\
(0.183)\end{array}$ & $\begin{array}{l}-0.977^{* *} \\
(0.434)\end{array}$ \\
\hline GExp & $\begin{array}{l}-0.627 \\
(1.639)\end{array}$ & $\begin{array}{l}-0.330 \\
(0.733)\end{array}$ & $\begin{array}{l}0.366 \\
(0.384)\end{array}$ & $\begin{array}{l}0.221 \\
(0.255)\end{array}$ \\
\hline No. of obs & 188 & 181 & 221 & 189 \\
\hline$R^{2}$ & 0.29 & 0.31 & 0.43 & 0.36 \\
\hline F- stat & 7.03 & 6.88 & 7.04 & 9.85 \\
\hline $\begin{array}{l}\text { Prob(F- } \\
\text { stat) }\end{array}$ & 0.00 & 0.00 & 0.00 & 0.00 \\
\hline
\end{tabular}

The estimated coefficients are given in the table followed by the standard errors in parenthesis. ${ }^{* * *},{ }^{* *},{ }^{*}$ indicates the level of significance at the $1 \%, 5 \%$, and $10 \%$, respectively

This means that government expenditure reduces the cost of doing business. This means that governments are extending more funds to the private sector. Similarly, the GDP growth is negatively related to the cost to start a business and positively related to the new business density. This result implies that economic prosperity in the country helps the business community. Economic prosperity reduces the time and costs to start a business.

The second phase of regression is for doing the business. The estimated coefficient of education shows that it is positively and significantly related to the cost of exports and negatively related to the trade barriers. The results show that economic incentives lead to increase in trade barriers and decrease in the cost of exports. The results also indicate that the institutional regime was not significantly related to doing business. All results are statistically insignificant for doing the business. The estimated coefficient of ICT shows that cost of exports and trade tariffs is negatively and significantly related to ICT. The cost of exports is reduced due to decrease in cost of information. The ICT helps to reduce the trade tariffs as well due to decrease in the cost of information and increase in competition in an economy. The control variable inflation shows that an increase in inflation reduces trade openness and trade tariff.

The estimated coefficient of education indicates that it increases the cost of exports and reduces trade tariffs. The estimated coefficients of education reveal an insignificant relation with Trade openness, ICT goods export, and high-technology exports. Furthermore, the estimated coefficient of education shows that it is positively and significantly related to the ICT Services export. An increase in education also increases the ICT Services exports. The estimated coefficient of economic incentive proves that its increase results in the decrease in cost of exports and trade barriers and increase in ICT Services exports. The results are following the findings of Suh and Chen [64]. ICT also affects the cost of exports and trade barriers negatively. The result implies that more ICT within an economy results in a decrease in cost of exports and trade barriers. This implies that it favors the businessmen by reducing the cost of exports and trade barriers. The results further proved that export of ICT goods and hightechnology exports are increased by ICT. It means that an increase in the ICT helps to increase the ICT goods exports and high-technology exports.

About innovation in the economy, the estimated coefficient of Innovex shows that it increases ICT goods export. However, the results further show that innovation decreases trade barriers; IT services export and hightechnology exports. The estimated coefficient of inflation shows that it is positively and significantly related to the cost of exports. The result implies that high inflation results in more uncertainty in the prices and interest rates. Inflation increases ICT goods exports and high-technology exports. Government expenditure is negatively related to the cost of exports and trade tariffs. GDP growth is positively related to ICT goods export and high-technology exports. The estimated coefficient of education shows that it is negatively related to contract enforcement. The economic incentives lead to increase the investment protection disclosure. The results further prove that institutional regimes decrease the time of registration of property. The estimated coefficient of inflation shows that it is negatively and significantly related to the contract enforcement and registration of property.

Education decreases contract enforcement time. ICT is negatively related to contract enforcement time and private property registration time. However, it is positively and significantly related to business disclosure. The institutional regime has a negative impact on the registration of property and business disclosure. The results are similar to Fosu [24] and Andrés et al. [4]. GDP growth 
is negatively associated with business disclosure. Inflation decreases contract enforcement and registration of property time. The estimated coefficient of education, economic incentives, innovation suggests that these variables have no significant impact on closing the business. The institutional regime is significantly and negatively related to the closing of the business. The results are similar to $[6,7,65]$. The GDP growth is also showing a negative but significant relationship to the closing of the business.

\section{Conclusion}

The study has scrutinized the role of KE in Asian business using the data of 45 countries for the period 20002019. The KE indicators used in the study are education, innovation, economic incentives, and institutional regime, and ICT. The business indicators are classified into starting, doing, and closing business. The KE indicators are reduced using the PCA to control the issues of multi-colinearity and over-parameterization. The estimation techniques used in the study are instrumental variable panel fixed effects. The importance of the research lies in the fact that the literature on the KE and business is scarce in Asia. This study adds to the literature of growing challenges of improving the Asian business climate, emphasizing KE. The findings reveal that education and ICT help to decrease the time and cost to start a business. Economic incentives also help to reduce the cost of starting a business but also increase the business density and the number of businesses. Innovation also helps to increase the number of businesses and business density as well. The findings further suggest that institutional regime decreases the chances of a business closure. GDP growth is also showing a negative but significant relationship to the closing of the business.

The results suggest that Asian countries need to invest more in education. There is a lack of investment in the education sector. The findings suggest a dire need to improve knowledge infrastructure, human skill development, the relationship between science and industry, and support for R\&D. Therefore, Asian countries need to improve their existing educational strategies to obtain more benefits from starting and doing business. There is a need to pay more attention to small ventures, business start-ups, and entrepreneurial lesions in the management specializations. The policymakers and regulators must foster high-caliber scientists and engineers capable of handling growth and challenges in technology and science. Similarly, ICT policies need to be articulated by improving human resources, entrepreneurial activities, $R \& D$, market liberalization, and privatization, and the construction of advanced infrastructure. The rigorous R\&D programs are important for the success of Asian countries. Innovation, with a strong ICT, economic incentives coupled with highly skilled labor, and human resources lead to an increase in the businesses in the economy results in the growth of the industry. There must be certain relaxation in the property rights in order to facilitate innovation in the business climate. The policymakers may confront the corruption in business circles while improving institutional quality. Hence, credible and effective government strategies are essential to attain long-run business development.

This study is one of the pioneer studies to investigate the role of KE on Asian businesses. Future research can be done to compare the differences in the role of knowledge economy in the different countries of Asia.

\section{Appendix}

See Tables 5 and 6 .

Table 5 List of sample countries

\begin{tabular}{lllllll}
\hline Azerbaijan & Bangladesh & South Korea & Kyrgyzstan & Singapore & Sri Lanka & Syria \\
\hline China & Bahrain & Iraq & Kazakhstan & Oman & Palestine & Maldives \\
India & Brunei & Afghanistan & Cambodia & Kuwait & Timor-Leste & UAE \\
Indonesia & Philippines & Malaysia & Jordon & Georgia & Cyprus & Qatar \\
Pakistan & Vietnam & Yemen & Tajikistan & Mongolia & Uzbekistan & Laos \\
Turkey & Iran & Nepal & Israel & Armenia & Bhutan & North Korea \\
Thailand & Myanmar & Saudi Arabia & & & & \\
\hline
\end{tabular}


Table 6 Variables description

\begin{tabular}{|c|c|}
\hline Variables & Variables definitions \\
\hline \multicolumn{2}{|l|}{ Panel A A1: Education } \\
\hline Primary School Enrollment (PSE) & School enrollment, primary (\% of gross) \\
\hline Secondary School Enrollment (SSE) & School enrollment, secondary (\% of gross) \\
\hline Tertiary School Enrollment (TSE) & School enrollment, tertiary (\% of gross) \\
\hline Education in KE (Educatex) & First PC of PSE, SSE \& TSE \\
\hline \multicolumn{2}{|l|}{ A2: Information \& Infrastructure } \\
\hline Internet Users (Internet) & Internet users (per 100 people) \\
\hline Mobile Cellular Subscriptions (Mobile) & Mobile subscriptions (per 100 people) \\
\hline Telephone lines (Tel) & Telephone lines (per 100 people) \\
\hline Information \& Communication Technology (ICT) in KE(ICTex) & First PC of Internet, Mobile \& Tel \\
\hline \multicolumn{2}{|l|}{ A3: Economic Incentive \& Institutional Regime } \\
\hline Financial Activity (Pcrbof) & Private domestic credit from banks and other financial institutions \\
\hline Interest Rate Spreads (IRS) & Lending rate minus deposit rate (\%) \\
\hline Economic Incentive in KE(Creditex) & First PC of Pcrbof and IRS \\
\hline Corruption-Control (CC) & $\begin{array}{l}\text { Control of Corruption (estimate): } \\
\text { Captures perceptions of the extent to which public power is exercised for private gain, } \\
\text { including both petty and grand forms of corruption, as well as 'capture' of the state by elites } \\
\text { and private interests" }\end{array}$ \\
\hline Rule of Law (RL) & $\begin{array}{l}\text { "Rule of Law (estimate): Captures perceptions of the extent to which agents have confi- } \\
\text { dence in and abide by the rules of society and in particular the quality of contract enforce- } \\
\text { ment, property rights, the police, the courts, as well as the likelihood of crime and violence" }\end{array}$ \\
\hline Regulation Quality (RQ) & $\begin{array}{l}\text { "Regulation Quality (estimate): Measured } \\
\text { as the ability of the government to formulate and implement sound policies and regula- } \\
\text { tions that permit and promote private sector }\end{array}$ \\
\hline Political Stability/ No violence & $\begin{array}{l}\text { "Political Stability/ No Violence } \\
\text { (estimate): Measured as the perceptions of the likelihood that the government will be desta- } \\
\text { bilized or overthrown by unconstitutional and violent means, including domestic violence } \\
\text { and terrorism" }\end{array}$ \\
\hline GovernmentEffectiveness (GE) & $\begin{array}{l}\text { "GovernmentEffectiveness (estimate): } \\
\text { Measures the quality of public services, the quality and degree of independence from politi- } \\
\text { cal pressures of the civil service, the quality of policy formulation and implementation, and } \\
\text { the credibility of governments commitments to such policies" }\end{array}$ \\
\hline Voice \& Accountability (VA) & $\begin{array}{l}\text { "Voice and Accountability (estimate): } \\
\text { Measures the extent to which a country's citizens can participate in selecting their govern- } \\
\text { ment and to enjoy freedom of expression, freedom of association, and a free media" }\end{array}$ \\
\hline Institutional Regime in KE(Instireg) & First PC of $C C, R L, R Q, P S, G E$, and VA \\
\hline Scientific \& Technical Publications (STJA) STJA & "Number of Scientific \& Technical Journal Articles" \\
\hline Trademark Applications (Trademark) & "Total Trademark Applications" \\
\hline Patent Applications (Patents) & "Total Residents + Nonresident Patent Applications" \\
\hline Innovation in KE (Innovex) & First PC of Trademarks and Patents \\
\hline \multicolumn{2}{|l|}{ Panel B: Business Indicators B1: Starting Business } \\
\hline Time to Start-up (Timestart) & "Log of Time required to start a business (days)" \\
\hline Cost of Start-up (Coststart) & "Log of Cost of business start-up procedures (\% of GNI per capita)" \\
\hline New business density (Newbisden) & "New business density (new registrations per 1,000 people ages $15-64$ )" \\
\hline Newly registered businesses (Newbisreg) & "Log of New businesses registered (number)" \\
\hline \multicolumn{2}{|l|}{ B2: Doing Business B2a: Trade } \\
\hline Cost of Export(Costexp) & "Log of Cost to export (US\$ per container)" \\
\hline Trade Barriers (Tariffs) & "Tariff rate, applied, weighted mean, all products (\%)" \\
\hline Trade Openness (TO) & "Export plus Import of Commodities (\% of GDP)" \\
\hline \multicolumn{2}{|l|}{ B2b: Technology Exports } \\
\hline ICT Goods Exports (ICTgoods) & "ICT goods exports (\% of total goods exports)" \\
\hline ICT Service Exports (ICTser) & "ICT service exports (\% of service exports, BoP)" \\
\hline High-Technology Exports (Hightecexp) & "High-technology exports (\% of manufactured exports)" \\
\hline
\end{tabular}


Table 6 (continued)

\begin{tabular}{|c|c|}
\hline Variables & Variables definitions \\
\hline \multicolumn{2}{|l|}{ B2c: Property Rights } \\
\hline $\begin{array}{l}\text { Contract Enforcement (Contenfor) Contenfor Log of Time } \\
\text { required to enforce a contract }\end{array}$ & "Log of Time required to enforce a contract" \\
\hline Registration of Property (Regprop) & $\begin{array}{l}\text { Log of Time required to register property (days) "Business extent of disclosure index }(0=\text { less } \\
\text { disclosure to } 10=\text { more disclosure) }\end{array}$ \\
\hline Investor Protection (Bisdiclos) & $\begin{array}{l}\text { It measures the extent to which investors are protected through disclosure of ownership } \\
\text { information" }\end{array}$ \\
\hline \multicolumn{2}{|l|}{ B3: Closing Business } \\
\hline Insolvency Resolution (Insol) & $\begin{array}{l}\text { "Time to resolve insolvency (years). The number of years from the filling of insolvency in } \\
\text { court until the resolution of distressed assets" }\end{array}$ \\
\hline \multicolumn{2}{|l|}{ Panel C: Control Variables } \\
\hline Government Expenditure (GExp) & Government final consumption expenditure (\% of GDP) \\
\hline Inflation (Inf) & Consumer Price Index (annual \%) \\
\hline GDP (GDPg) & Growth Rate (annual \%) \\
\hline
\end{tabular}

\section{Abbreviations}

KBE: Knowledge-based economy; KE: Knowledge economy; R \& D: Research and development; ICT: Information and Communication Technology.

\section{Acknowledgements}

I would like to acknowledge our Head of the Campus Sir Khusro Pervez Khan and our Head of Department Dr. M Asif Khan for always being a source of motivation and inspiration.

\section{Authors' contributions}

The main contribution of this study is that it adds in the literature of growing challenges of improving the Asian business climate with a major emphasis on Knowledge Economy. The findings of the study open new doors for the policymakers, regulators, and the management of the business community with more emphasis on Knowledge Economy. The author read and approved the final manuscript.

\section{Funding}

There has been no significant financial support for this work that could have influenced its outcome.

\section{Availability of data and materials}

The data can be made available upon request.

\section{Declarations}

\section{Conflict of interests}

I declare that this work is original and is not considered for publication in any other journal.

\section{Competing interests}

I have no conflicts of interest associated with this publication.

Received: 20 October 2020 Accepted: 21 December 2021

Published online: 20 January 2022

\section{References}

1. Agénor PR, Neanidis KC (2015) Innovation, public capital, and growth. J Macroecon 44(1):252-275

2. Ahmed EM, Ridzuan R (2013) The impact of ICT on East Asian economic growth: panel estimation approach. J Knowl Econ 4(4):540-555

3. Amavilah V, Asongu SA, Andrés AR (2017) Effects of globalization on peace and stability: implications for governance and the knowledge economy of African countries. Technol Forecast Soc Chang 122(1):91-103
4. Andrés AR, Asongu SA, Amavilah V (2015) The impact of formal institutions on knowledge economy. J Knowl Econ 6(4):1034-1062

5. Anyanwu JC (2012) Developing knowledge for the economic advancement of Africa. Int J Acad Res Econ Manage Sci 1(2):73-111

6. Asongu S (2015) The impact of mobile phone penetration on African inequality. Int J Soc Econ 42(8):706-716

7. Asongu SA (2015) Software piracy and scientific publications: knowledge economy evidence from Africa. Afr Dev Rev 26(4):572-583

8. Asongu SA (2017) Knowledge economy gaps, policy syndromes, and catch-up strategies: fresh South Korean lessons to Africa. J Knowl Econ 8(1):211-253

9. Asongu SA, Andrés AR (2019) Trajectories of knowledge economy in SSA and MENA countries. Technol Soc 63(4):101119

10. Asongu SA, Tchamyou VS (2016) The impact of entrepreneurship on knowledge economy in Africa. J Entrep Emerg Econ 8(1):101-131

11. Asongu SA, Amavilah VH, Andres AR (2020) Business dynamics, knowledge economy, and the economic performance of African countries. Inf Dev 36(1):128-152

12. Barkhordari S, Fattahi M, Azimi NA (2019) The impact of knowledge-based economy on growth performance: evidence from MENA countries. J Knowl Econ 10(3):1168-1182

13. Bogoviz AV, Ragulina YV, Alekseev AN, Anichkin ES, Dobrosotsky VI (2017) Transformation of the role of human in the economic system in the conditions of knowledge economy creation. In: International conference on humans as an object of study by modern science. Springer, Cham, pp 673-680

14. Bogoviz AV, Shvakov EE, Tretyakova OG, Zakharov MY, Abramov AN (2020) Globalization of education in the conditions of formation of the global knowledge economy: regularities and tendencies. Growth Poles Global Econ Emergence Chang Future Perspect 73(1):993-1000

15. Castellacci F, Natera JM (2016) Innovation, absorptive capacity and growth heterogeneity: development paths in Latin America 1970-2010. Struct Chang Econ Dyn 37:27-42

16. Chavula HK, Konde V (2011) Innovation and industrial development in Africa. ATDF J 8(3/4):3-12

17. Das DK, Erumban AA, Aggarwal S, Das PC (2015) Measuring productivity at the industry level: the India KLEMS database. Data Manual

18. Datta A, Agarwal S (2004) Telecommunications and economic growth: a panel data approach. Appl Econ 36(15):1649-1654

19. Demeulemeester JL, Diebolt C (2011) Education and growth: what links for which policy? Historic Soc Res 36(4):323-346

20. Demombynes G, Thegeya A (2012) Kenya's mobile revolution and the promise of mobile savings. The World Bank.

21. Dima AM, Begu L, Vasilescu MD, Maassen MA (2018) The relationship between the knowledge economy and global competitiveness in the European Union. Sustainability 10(6):1706-1721 
22. Evoh CJ, Mugimu CB, Chavula HK (2014) Knowledge production in the knowledge economy: Higher education institutions and the application of innovations in ICT for capacity development in Africa. Dev Higher Educ Africa Prospect Challeng 21(1):285-323

23. Flachaire E, García-Peñalosa C, Konte M (2014) Political versus economic institutions in the growth process. J Comp Econ 42(1):212-229

24. Fosu AK (2013) Impact of the global financial and economic crisis on development: whither Africa? J Int Dev 25(8):1085-1104

25. Gabriele R, D'Ambrosio A, Schiavone F (2017) Open innovation and the role of hubs of knowledge in a regional context. J Knowl Econ 8(3):1049-1065

26. Gerba DT (2012) Impact of entrepreneurship education on entrepreneurial intentions of business and engineering students in Ethiopia. Afr J Econ Manag Stud 3(2):258-277

27. Gyimah-Brempong K, Paddison O, Mitiku W (2006) Higher education and economic growth in Africa. J Dev Stud 42(3):509-529

28. Hadad S (2017) Knowledge economy: Characteristics and dimensions. Manage Dyn Knowl Econ 5(2):203-225

29. Harris R, Ormond B (2019) Historical knowledge in a knowledge economy-what types of knowledge matter? Educ Rev 71(5):564-580

30. Hassan G, Cooray A (2015) Effects of male and female education on economic growth: Some evidence from Asia. J Asian Econ 36:97-109

31. Hellebrandt T, Mauro P (2015) The future of worldwide income distribution. Peterson Institute for international economics working paper, pp $7-15$

32. Hippe RTK, Fouquet R (2018) The knowledge economy in historical perspective. World Econ 18(1):75-107

33. Hongyi LI, Huang L (2009) Health, education, and economic growth in China: Empirical findings and implications. China Econ Rev 20(3):374-387

34. Inekwe JN (2015) The contribution of R\&D expenditure to economic growth in developing economies. Soc Indic Res 124(3):727-745

35. Ishida H (2015) The effect of ICT development on economic growth and energy consumption in Japan. Telemat Inform 32(1):79-88

36. Jacob M, Hellström T (2014) Opportunity from crisis: a common agenda for higher education and science, technology and innovation policy research. Stud High Educ 39(8):1321-1331

37. Jorgenson AK, Givens J (2015) The changing effect of economic development on the consumption-based carbon intensity of well-being, 1990-2008. PLoS ONE 10(5):e0123920

38. Kogut B, Zander U (1992) Knowledge of the firm, combinative capabilities, and the replication of technology. Organ Sci 3(3):383-397

39. Lee SK, Mogi G, Kim JW (2009) Energy technology roadmap for the next 10 years: the case of Korea. Energy Policy 37(2):588-596

40. Liargovas P, Repousis S (2015) Development paths in the knowledge economy: innovation and entrepreneurship in Greece. J Knowl Econ 6(4):1063-1077

41. Lucas RE Jr (1988) Money demand in the United States: a quantitative review. Carnegie-Rochester Conferen Ser Public Policy 29(1):137-167

42. Martín-de Castro G (2015) Knowledge management and innovation in knowledge-based and high-tech industrial markets: the role of openness and absorptive capacity. Ind Mark Manage 47:143-146

43. Martinez-Fernandez C, Weyman T (2014) Skills Development for the Knowledge Economy in Asia: some conclusions from the OECD experience. Prospects 44(2):249-266

44. Mêgnigbêto E (2018) Correlation between transmission power and some indicators used to measure the knowledge-based economy: case of six OECD countries. J Knowl Econ 9(4):1168-1183

45. Mensah SN, Benedict E (2010) Entrepreneurship training and poverty alleviation: empowering the poor in the Eastern Free State of South Africa. Afr J Econ Manag Stud 1(2):138-163

46. Moodie G, Wheelahan L (2009) The significance of Australian vocational education institutions in opening access to higher education. High Educ Q 63(4):356-370

47. Muzaka V (2019) India and Brazil in pursuit of the competitive knowledge economy. Rev Int Stud 45(2):345-364

48. Naqshbandi MM, Jasimuddin SM (2018) Knowledge-oriented leadership and open innovation: role of knowledge management capability in France-based multinationals. Int Bus Rev 27(3):701-713

49. Niininen P (1998) Computers and economic growth in Finland WIDER Working Paper Series World Institute for Development Economic Research (UNUWIDER) 148
50. Nurunnabi M (2017) Transformation from an oil-based economy to a knowledge-based economy in Saudi Arabia: the direction of Saudi vision 2030. J Knowl Econ 8(2):536-564

51. Poh KL, Ang BW, Bai F (2001) A comparative analysis of R\&D project evaluation methods. R\&D Manage 31(1):63-75

52. Qamruzzaman M, Jianguo W (2017) Financial innovation and economic growth in Bangladesh. Financ Innovat 3(1):1-24

53. Raspe O, Van Oort F (2006) The knowledge economy and urban economic growth. Eur Plan Stud 14(9):1209-1234

54. Roller LH, Waverman L (2001) Telecommunications infrastructure and economic development: a simultaneous approach. Am Econ Rev 91(4):909-923

55. Romer PM (1986) Increasing returns and long-run growth. J Polit Econ 94(5):1002-1037

56. Romer PM (1987) Growth based on increasing returns due to specialization Am Econ Rev 77(2):56-62

57. Sadorsky P (2012) Information communication technology and electricity consumption in emerging economies. Energy Policy 48:130-136

58. SchultzTW (1961) Investment in human capital. Am Econ Rev 51(1):1-17

59. Shahabadi A, Kimiaei F, Afzali MA (2018) The evaluation of impacts of knowledge-based economy factors on the improvement of total factor productivity (a comparative study of emerging and G7 economies). J Knowl Econ 9(3):896-907

60. Shahbaz M, Rehman IU, Sbia R, Hamdi H (2016) The role of information communication technology and economic growth in recent electricity demand: Fresh evidence from combine cointegration approach in UAE. J Knowl Econ 7(3):797-818

61. Shmelev SE, Sagiyeva RK, Kadyrkhanova ZM, Chzhan YY, Shmeleva IA (2018) Comparative sustainability analysis of two Asian cities: a multidimensional assessment of Taipei and Almaty. J Asian Finance Econ Bus 5(3):143-155

62. Storey J, Salaman G (2009) Managers of innovation: insights into making innovation happen. Wiley

63. Singh M (2011) The place of social justice in higher education and social change discourses. Compare A J Comparat Int Educ 41(4):481-494

64. Suh J, Chen DHC (eds) (2007) Korea as a knowledge economy: evolutionary process and lessons learned. The World Bank

65. Tchamyou VS (2017) The role of knowledge economy in African business. J Knowl Econ 8(4):1189-1228

66. Unger RM (2019) Rethinking the knowledge economy. Am Affairs $3(2): 3-24$

67. Wantchekon L, Klašnja M, Novta N (2015) Education and human capital externalities: evidence from colonial Benin. Q J Econ 130(2):703-757

68. White DS, Gunasekaran A, Ariguzo GC (2013) The structural components of a knowledge-based economy. Int J Bus Innovat Res 7(4):504-518

69. Woods P, Jeffrey B, Troman G, Boyle M (2019) Restructuring schools, reconstructing teachers: Responding to change in the primary school. Routledge

70. Young M, Muller J (2010) Three educational scenarios for the future: Lessons from the sociology of knowledge. Eur J Educ 45(1):11-27

\section{Publisher's Note}

Springer Nature remains neutral with regard to jurisdictional claims in published maps and institutional affiliations.

\section{Submit your manuscript to a SpringerOpen ${ }^{\odot}$ journal and benefit from:}

- Convenient online submission

- Rigorous peer review

- Open access: articles freely available online

- High visibility within the field

- Retaining the copyright to your article

Submit your next manuscript at springeropen.com 